\title{
FOUR NEW SPECIES OF CRANICHIS (ORCHIDACEAE, SPIRANTHOIDEAE, CRANICHIDINAE) FROM COLOMBIA
}

\author{
DARIUSZ L. SZLACHETKO \& MARTA KOLANOWSKA ${ }^{1}$
}

\begin{abstract}
Four new species of the Neotropical genus Cranichis Sw. are described and illustrated based on Colombian material. The new entities are placed within a key for identification of Colombian members of the genus. Information about their ecology and distribution is provided.
\end{abstract}

Key words: Andes, biodiversity, Neotropics, taxonomy

Dariusz L. Szlachetko \& Marta Kolanowska, Department of Plant Taxonomy and Nature Conservation, University of Gdańsk, ul. Wita Stwosza 59, 80-308 Gdańsk, Poland; e-mail: martakolanowska@wp.pl

\section{INTRODUCTION}

Consisting of over 3000 species, the Colombian orchid flora is one of the world's richest (Ortiz Valdivieso \& Uribe Vélez 2007). The subfamily Spiranthoideae is represented by over 200 species within ca 30 genera (Dueñas Gómez \& FernándezAlonso 2007, 2009; Ormerod 2007, 2008, 2009a, b). While generic delimitation among the Neotropical terrestrial orchids is the subject of ongoing discussion between taxonomists around the world due to the incompatibility of morphological (Dressler 1993; Szlachetko 1995; Szlachetko \& Rutkowski 2010) and molecular findings (Salazar et al. 2003; Álvarez-Molina \& Cameron 2009), the separateness of Cranichis Sw. is not questioned.

The genus was first described by Olof Swartz in 1788, and the nominal species C. muscosa Sw. was selected more than 150 years later by Acuña (1939). Morphologically Cranichis is clearly defined since the transfer of two monotypic taxa, Pseudocranichis Garay and Exalaria Garay $\&$ G. A. Romero, from the genus.

Species of the genus are easily distinguished from other cranichioid orchids by their villoushairy roots, distinctly petiolate, suberect or arcuately spreading leaves, nonresupinate flowers,

\footnotetext{
1 Corresponding author
}

petals much narrower than sepals, and cochleate lip, often with conspicuously marked, colored reticulate veins. The gynostemium is relatively massive, often swollen at the apex, without a column-foot. The motile anther is oblong to ovate and 2-chambered. The inconspicuous caudiculae are formed from the apices of pollinia. The clinandrium is usually thick, massive and spacious. The single viscidium is thick and relatively small, and the hamulus is usually elongate, finger-like, thick, and directed towards the anther (Szlachetko \& Rutkowski 2010).

Representatives of Cranichis are found in lowlands as well as in montane forest growing terrestrially or lithophytically, usually in humus and Sphagnum tussocks. Their occurrence has been reported from 350 up to $3000 \mathrm{~m}$ a.s.l. (Carnevali \& Ramírez-Morillo 2003; Cribb 2003).

As currently recognized, the genus embraces $c a$ 60 species distributed from Florida and Mexico to Bolivia and Argentina. Ortiz Valdivieso and Uribe Vélez (2007) placed 19 species of Cranichis in the most recent list of Colombian Orchidaceae. Most of the national representatives, except Crachinis muscosa and C. parvula Ranz, were found in Columbia's submontane and montane regions in litter of the Andean forest and shrubs of subparamo and 
paramo. Their occurrence in Colombia was also reported from pastures and rocky slopes (Dueñas Gómez \& Fernández-Alonso 2009). The last comprehensive revision of Colombian Cranichis was made over 50 years ago (Schneider 1953), but the recent studies on the national Orchidaceae revealed the existence of two new species in the country (Szlachetko \& Kolanowska 2013).

During the course of study on north Andean Cranichidinae, three distinct species of Cranichis were found and are described here as new.

\section{DESCRIPTIONS OF THE NEW SPECIES}

Cranichis cristalinensis Szlach. \& Kolan., sp. nov.

Fig. 1

Species appears similar to C. sylvatica A. Rich. \& Gal. and $C$. werffii Garay but the petals are widest at the apex and the lip is sessile, suborbicular, much thickened in the center.

HolotyPE: COLOMBIA, Cundinamarca, Fomeca. Vda. La Cristalina. Parque Nacional Natural Chingaza. Laguna de Chingaza. Sector La Playa. Bosque de Drymis granatensis, planta terrestra, flores blancas, $4^{\circ} 31^{\prime} 50^{\prime \prime} \mathrm{N}$,

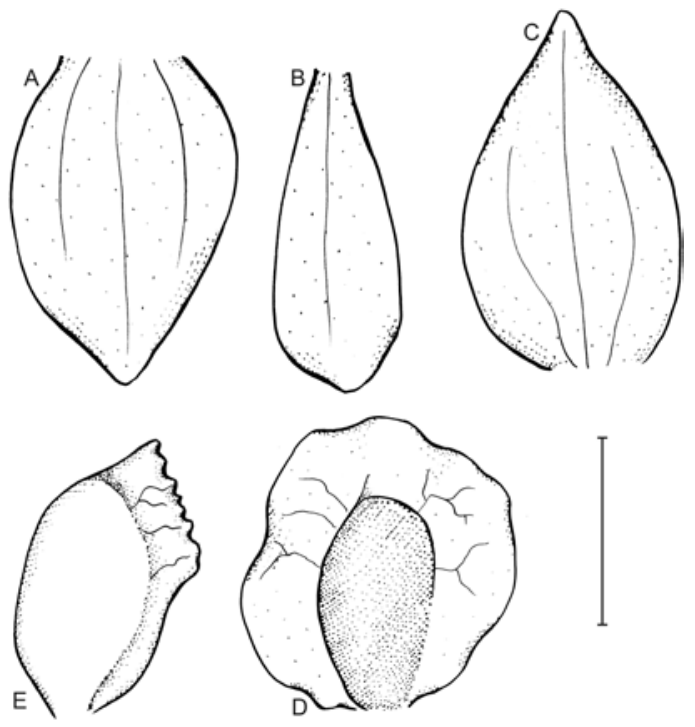

Fig. 1. Cranichis cristalinensis Szlach. \& Kolan., sp. nov. dissected perianth. A - dorsal sepal; B - petal; C - lateral sepal; D - lip; E - lip (side view). Drawn by S. Nowak from the holotype. Scale bar $=2 \mathrm{~mm}$.

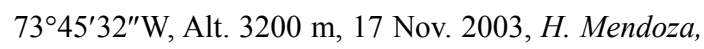
O. Vargas \& O. Borbon 15473 (COL).

Plants to $40 \mathrm{~cm}$ tall. Leaves 2, basal, petiolate; petiole to $6.5 \mathrm{~cm}$ long, narrow; blade up to $5.3 \mathrm{~cm}$ long and $2.2 \mathrm{~cm}$ wide, oblong- or ovate-lanceolate, acute, rounded or truncate at base. Scape erect, delicate, glandular in the upper third, enclosed in 4 sheaths. Inflorescence to $5.5 \mathrm{~cm}$ long, subdensely many-flowered. Flowers small, inconspicuous. Floral bracts $4.5 \mathrm{~mm}$ long, lanceolate, acuminate, glabrous or sparsely glandular. Pedicel and ovary up to $7.5 \mathrm{~mm}$ long, papillate. Sepals glabrous. Dorsal sepal $3.5 \mathrm{~mm}$ long, $2.1 \mathrm{~mm}$ wide, ovate, subobtuse, rather cochleate in center, 3-nerved. Petals $3.1 \mathrm{~mm}$ long, $1.3 \mathrm{~mm}$ wide, oblong-spathulate, rounded at apex, subfalcate, glabrous along margins, 1-nerved. Lateral sepals $3.2 \mathrm{~mm}$ long, $2.1 \mathrm{~mm}$ wide, ovate to elliptic-ovate, acute to shortly acuminate, somewhat oblique, slightly concave, 3-nerved. Lip $3 \mathrm{~mm}$ and wide, suborbicular in outline, sessile, greatly thickened in center, apical margins slightly wavy. Gynostemium $1.8 \mathrm{~mm}$ long.

ETYMOLOGY. In reference to the name of the place of origin of the type specimen.

ECOLOGY. Terrestrial in high-montane forest with Drimys granadensis (Winteraceae) at $c a$ $3200 \mathrm{~m}$ a.s.1. Flowering in November.

Distribution. So far known only from the Eastern Cordillera of the Andes, Colombian department of Cundinamarca.

Notes. Cranichis cristalinensis seems related to C. sylvatica A. Rich. \& Gal. and C. werffii Garay, but is easily separable from both species by the petals and lip form. The petals of the new entity are widest at the apex and the lip is sessile, suborbicular, and much thickened in the center.

Cranichis queremalensis Szlach. \& Kolan., sp. nov.

Fig. 2

Species similar to C. parvula Renz but the petals are attenuate toward the base and apex with only the outer margin shortly and densely ciliate, and the lip ellipticsuborbicular, very thin, and almost flat with a recurved apex. 


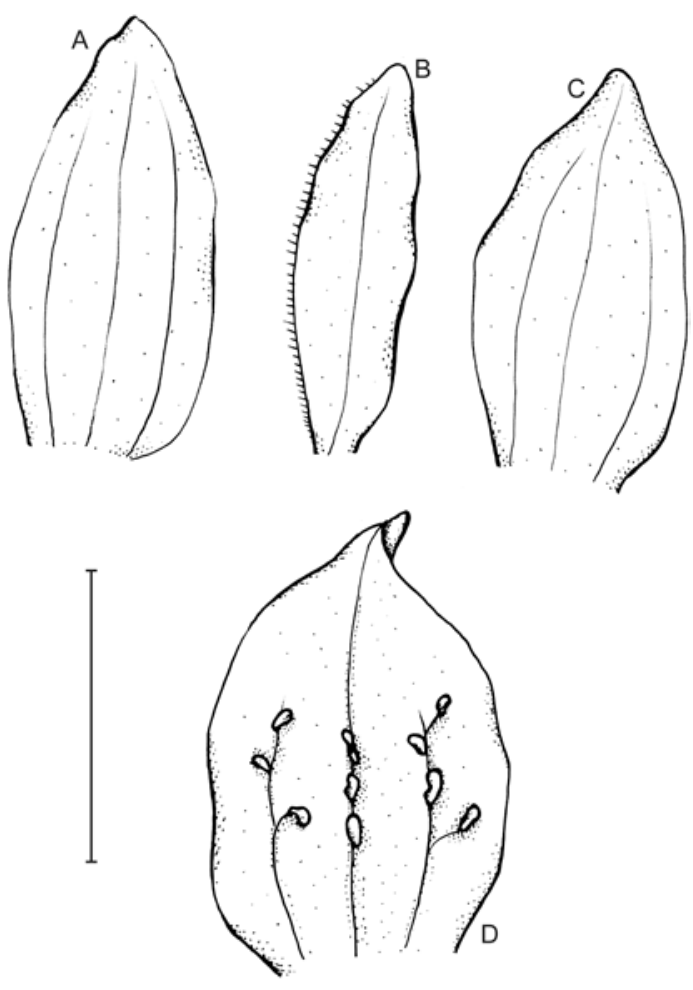

Fig. 2. Cranichis queremalensis Szlach. \& Kolan., sp. nov. - dissected perianth. A - dorsal sepal; B - petal; C - lateral sepal; D - lip. Drawn by S. Nowak from the holotype. Scale bar $=2 \mathrm{~mm}$.

Holotype: COLOMBIA, Valle del Cauca, Dagua. Corregimiento El Queremal, 0-6 km carretera El Queremal-Buenaventura. $3^{\circ} 31.42-81^{\prime} \mathrm{N}, 76^{\circ} 43.62-44.92^{\prime} \mathrm{W}$. Relictos bosque al lado de la carretera, Alt. 1430-1550 m, 30 Dec. 2009, M.F. Gonzalez, Betancur \& A. Zuluaga 168 (COL; ISOTYPE: FMB).

Plants to $20 \mathrm{~cm}$ tall. Leaves 3, basal, petiolate; petiole to $4.5 \mathrm{~cm}$ long, narrow; blade up to $4.5 \mathrm{~cm}$ long and $2 \mathrm{~cm}$ wide, elliptic-suborbicular, base subcordate, obtuse to subobtuse at apex. Scape erect, delicate, glabrous, enclosed distantly in 4 sheaths, of which the lower ones are leafy. Inflorescence to $4 \mathrm{~cm}$ long, subdensely many-flowered. Flowers small, inconspicuous. Floral bracts $4 \mathrm{~mm}$ long, lanceolate, acuminate, glabrous. Pedicel and ovary up to $8 \mathrm{~mm}$ long, glabrous. Sepals glabrous. Dorsal sepal $3 \mathrm{~mm}$ long, $1.1 \mathrm{~mm}$ wide, oblongelliptic-ovate, subobtuse, rather cochleate in center, 3-nerved. Petals $3 \mathrm{~mm}$ long, $0.6 \mathrm{~mm}$ wide, oblong-lanceolate, subacute to subobtuse, subfalcate, densely and shortly ciliate along outer margin except for base and apex, 1-nerved. Lateral sepals $3 \mathrm{~mm}$ long, $1.2 \mathrm{~mm}$ wide, ovate to elliptic-ovate, subobtuse to subacute, slightly oblique, slightly concave, 3-nerved. Lip $3 \mathrm{~mm}$ long, $2 \mathrm{~mm}$ wide, elliptic-suborbicular in outline, widest near middle, apex with short, triangular, recurved, acute apiculus, lamina almost flat, nerves 3 , obscure, with 1 or 2 branches and several knob-like swellings on nerves. Gynostemium $1.1 \mathrm{~mm}$ long.

ETYMOLOGY. In reference to the name of the place of origin of the type specimen of this species.

ECOLOGY. This species was found on the roadside in an area covered with premontane forest. Alt. 1430-1550 m. Flowering in December.

DistribUTION. So far it is known only from the pacific slope of the Western Andean Cordillera, department of Valle del Cauca Colombia.

NOTES. Cranichis queremalensis appears to be related to its Colombian-Ecuadorian congener C. parvula, originally described from the Colombian department of Meta. Cranichis queremalensis is characterized by petals attenuate toward the base and apex with only the outer margin shortly and densely ciliate, the lip elliptic-suborbicular, very thin, and almost flat with a recurved apex. Petals of $C$. parvula are oblong-ligulate, rounded at the apex and glabrous on the margins, with the lip similar in shape to $C$. queremalensis but cochleate in the center, with numerous knob-like projections and a straight apex.

Cranichis schlechteri Szlach. \& Kolan., sp. nov.

Fig. 3

Species similar to Ecuadorian C. macroblepharis Rchb. f. but with the lip prominently auriculate and petals long-ciliate along the margins.

Holotype: COLOMBIA, Huila. Mpio. La Plata. Vereda Agua Bonita. Finca Merenburg, Alt. 12001300 m, 20 Jul. 1975, S. Diaz P., G. Lozano C. \& J.H. Torres 745 (COL). 
Plants to $40 \mathrm{~cm}$ tall. Leaf 1, basal, petiolate; petiole to $3.5 \mathrm{~cm}$ long, narrow; blade up to $6 \mathrm{~cm}$ long and $3.7 \mathrm{~cm}$ wide, ovate, acute, subcordate at base. Scape erect, delicate, glabrous in lower half, otherwise glandular, enclosed in 5 sheaths. Inflorescence subdensely many-flowered. Flowers small, inconspicuous, glabrous. Floral bracts $5 \mathrm{~mm}$ long, lanceolate, acuminate. Pedicel and ovary up to $10 \mathrm{~mm}$ long. Dorsal sepal $4.5 \mathrm{~mm}$ long, $1.5 \mathrm{~mm}$ wide, oblong-ovate above narrow base and attenuate towards obtuse apex, rather cochleate in center, obscurely 3-nerved. Petals $4 \mathrm{~mm}$ long, $0.6 \mathrm{~mm}$ wide, oblong-lanceolate to linear-lanceolate, acute at apex, subfalcate, margins covered by long and soft cilia except base and apex, 1-nerved. Lateral sepals $4.5 \mathrm{~mm}$ long, $1.8 \mathrm{~mm}$ wide, ovate to elliptic-ovate, subobtuse, slightly oblique, slightly concave, obscurely 3-nerved. Lip $2.5 \mathrm{~mm}$ long, $1.6 \mathrm{~mm}$ wide, oblong-ovate in outline, sessile,

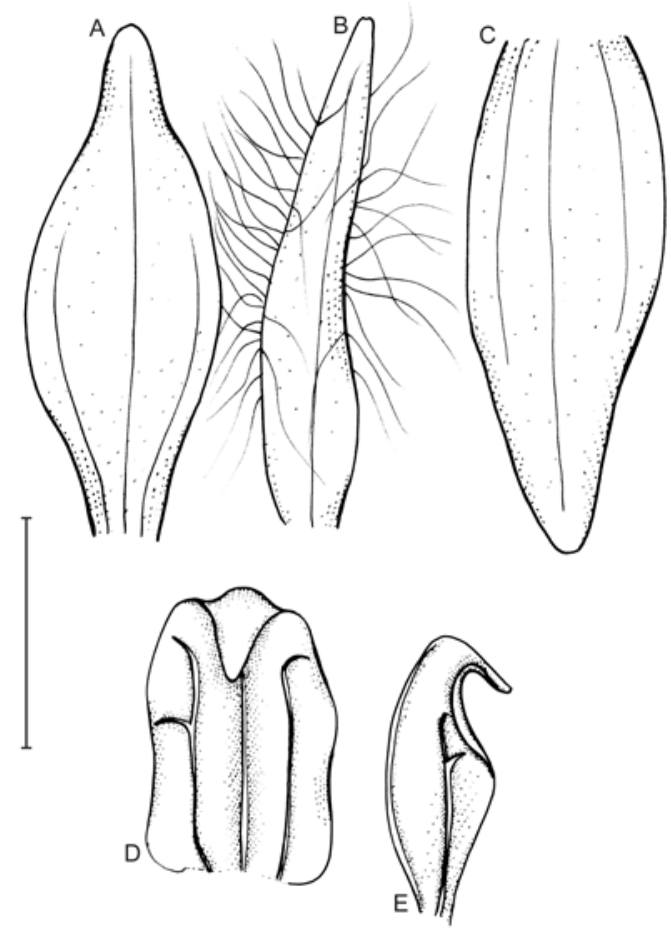

Fig. 3. Cranichis schlechteri Szlach. \& Kolan., sp. nov. - dissected perianth. A - dorsal sepal; B - petal; C - lateral sepal; D - lip; E - lip (side view). Drawn by S. Nowak from the holotype. Scale bar $=2 \mathrm{~mm}$. basally auriculated, apex elongate, subobtuse, incurved, nerves 3, protruding, sparsely branching. Gynostemium $1.5 \mathrm{~mm}$ long.

ETYMOLOGY. Named in honor of Rudolf Schlechter, an eminent orchid taxonomist.

ECOLOGY. No habitat record. Alt. 1200-1300 m. Flowering in July. This species most probably is autogamous.

DistribUTiOn. So far known only from the eastern slope of the Andean Central Cordillera, Colombian department of Huila.

Notes. The new species appears to be similar to its Ecuadorian congener C. macroblepharis but is easily separable from the latter by having an auriculate base of the lip and long-ciliate petal margins.

Cranichis rotundifolia Szlach. \& Kolan., sp. nov.

Fig. 4

Species similar to $C$. diphylla Sw. but distinguished by its suborbicular leaf blade, spathulate, apically rounded petals, and the lip broadly ovate and obtuse, with two anastomosed veins.

Holotype: COLOMBIA, Nariño, Pasto, Correg. de El Encano. Isla La Corota, Alt. 2700 m. 14 Nov. 1980, O. S. Benavides 2699 (PSO).

Plant up to $\mathrm{ca} 30 \mathrm{~cm}$ tall. Roots fleshy, fasciculate, puberulent. Leaf 1, basal, petiolate; petiole $c a$ $3 \mathrm{~cm}$ long; blade ca $5 \mathrm{~cm}$ long, $3.5 \mathrm{~cm}$ wide, suborbicular, subacute, subcordate at the base. Scape $c a$ $25 \mathrm{~cm}$ long, slender, erect, remotely few-sheathed; spike ca $6 \mathrm{~cm}$ long, densely many-flowered. Flowers glabrous, translucent white. Floral bracts 3-4 mm long, lanceolate, acute. Pedicel and ovary 5-6 mm long, very sparsely glandular-ciliate. Dorsal sepal $3.1 \mathrm{~mm}$ long, $1 \mathrm{~mm}$ wide, narrowly elliptic, obtuse, 3-veined. Petals $2.5 \mathrm{~mm}$ long, $1 \mathrm{~mm}$ wide, spathulate, apex rounded, 1-veined. Lateral sepals $2.9 \mathrm{~mm}$ long, $1.5 \mathrm{~mm}$ wide, obliquely ovate, subobtuse, 3-veined. Lip ca $2 \mathrm{~mm}$ long, $1.6 \mathrm{~mm}$ wide, concave, sessile, broadly ovate, obtuse, with two anastomosed veins. Gynostemium $1.1 \mathrm{~mm}$ long. 


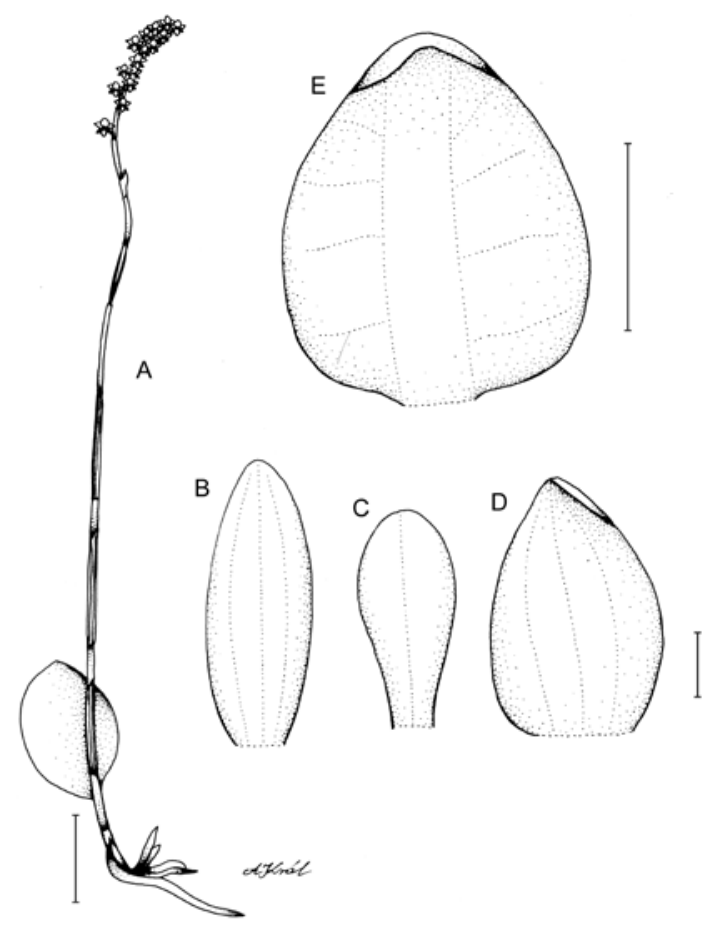

Fig. 4. Cranichis rotundifolia Szlach. \& Kolan., sp. nov. A habit. B - dorsal sepal; C - petal; D - lateral sepal; E - lip. Scale bars: $\mathrm{A}=3 \mathrm{~cm} ; \mathrm{B}-\mathrm{E}=1 \mathrm{~mm}$. Drawn by Anna Król from the holotype.

ETYMOLOGY. In reference to the leaf shape.

ECOLOGY. The species was found growing terrestrially on humid soil in high-montane humid forest. Alt. $2700 \mathrm{~m}$. Flowering in November.

Distribution. So far this species is known only from Laguna de la Cocha in southern Colombia.

Notes. Species similar to $C$. diphylla but distinguished by its suborbicular leaf blade (vs ovate to ovate-lanceolate), the spathulate, apically rounded petals (vs linear-oblanceolate, acute to obtuse) and the lip broadly ovate and obtuse, with two anastomosed veins (vs lip ovate to broadly elliptic, disc obcordately papillose-thickened with 3 branching, often glandular veins). Vegetatively the new species seems to resemble $C$. tenuis Rchb. f., from which it differs by the form of its perianth segments as well as by the shorter floral bracts and ovaries. In the floral parts $C$. rotundifolia resembles $C$. fendleri Schltr., especially in having spathulate petals and a broadly ovate lip. The two species are easily distinguished by a series of characters. In C. fendleri there are 3-4 oblong-elliptic to ovate-lanceolate, acute leaves, an oblong-lanceolate dorsal sepal and a lip with 3 anastomosed veins.

\section{KEY TO THE COLOMBIAN SPECIES OF CRANICHIS}

1. Petals with long hairs or cilia along the margins .. $\ldots \ldots \ldots \ldots \ldots \ldots \ldots \ldots \ldots$

1. Petals without long hairs on the margins . . . . 3

2. Lip ovate-saggitate in outline, acute, almost flat $\ldots \ldots \ldots \ldots \ldots$ C. wageneri Rchb. f.

2. Lip oblong-ovate in outline, apex elongate, sub-

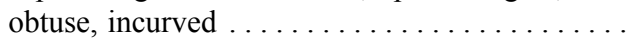
........... S. schlechteri Szlach. \& Kolan

3. Petals ciliate ................. 4

3. Petals with entire or slightly erose margins, glabrous ...................... 15

4. Scape glabrous ............... 5

4. Scape glandular or glandular-pubescent $\ldots .8$

5. Lip ovate-elliptic, base saccate

................. C. crumenifera Garay

5. Lip ovate to suborbicular . . . . . . . . . 6

6. Petals from a short claw broadly oblanceolate to elliptic ............ polyantha Schltr.

6. Petals linear-ligulate to oblong-oblanceolate . 7

7. Lip midvein unbranched ..... C. engelii Rchb. f. 7. All lip veins branching ......... C. muscosa

8. Ovary glandular ................ 9

8. Ovary glabrous . . . . . . . . . . . . . . 11

9. Lip without any additional projections on the surface .................... 10

9. Lip with spiculate pustules or knob-like projections C. schlimii Rchb. f.

10. Lateral sepals obscurely 3 -veined, lip obtuse at the apex ....... C. brachyblephara Schltr.

10. Lateral sepals obscurely 1 -veined, lip truncate at the apex with short, triangular, acute apiculus C. zarucchii Szlach. \& Kolan.

11. Inflorescence elongate, raceme 8-12 cm long, longer than the leaf blade ..... C. antioquiensis Schltr.

11. Raceme up to 4-7 $\mathrm{cm}$ long, shorter than the leaf blade ...................... 12

12. Leaf blade elliptic-suborbicular, obtuse to sub-

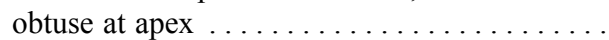
....... C. queremalensis Szlach. \& Kolan. 
12 . Leaf blade ovate to elliptic, acute or acuminate ................... 13

13. Flowers $c a 3 \mathrm{~mm}$ in diameter, ovary $c a 5-6 \mathrm{~mm}$ long .................. 14

13. Flowers $\mathrm{ca} 3.5 \mathrm{~mm}$ in diameter, ovary up to $11 \mathrm{~mm}$ long $\ldots \ldots \ldots \ldots \ldots$ C. ciliata (Kunth) Kunth

14. Sepals attenuate towards the apex, petals minutely ciliate along margins, lip longer than wide ............. C. pleioneura Schltr.

14* Sepals rounded at the apex, petals pubescent along margins, lip as long as wide ......... $\ldots \ldots \ldots \ldots$. . polyblephara Schltr.

15. Petals margins erose ....... C. picta Rchb. f.

15 . Petals margins entire ............. 16

16. Petals oblong-spathulate . . . . . . . . . 17

16. Petals linear-oblanceolate . . . . . . . . . . 18

17. Leaf one, blade suborbicular .............. ........... C. rotundifolia Szlach. \& Kolan.

$17^{*}$ Leaves 2, blade oblong- or ovate-lanceolate .... . . . . . . . . . C. cristalinensis Szlach. \& Kolan.

18. Leaves narrowly oblanceolate to linear-lanceolate .................... 19

18. Leaves ovate, ovate-lanceolate to orbicular . . ..................... 20

19. Lateral sepals obliquely oblong-triangular, outer margin not forming a lobe .............. .... C. lehmanniana (Kraenzl.) L. O. Williams

19*. Lateral sepals obliquely ovate with expanded basal outer margin forming a lobe ............. C. carlos-parrae Szlach. \& Kolan.

20. Leaves usually two, often one is much larger than the other $\ldots \ldots \ldots \ldots$ C. diphylla $\mathrm{Sw}$. 20. Leaves several, subequal in size ....... 21

21. Petals elliptic .......... C. gibbosa Lindl. 21*. Petals lanceolate to oblong-oblanceolate .... 22

22. Floral bracts subequal or longer than ovary ... .C. lehmannii Rchb. f. 22 . Floral bracts shorter than ovary . . . . . . 23

23. Leaf blade elliptic to orbicular; petiole $0.4 \mathrm{~cm}$ long; blade $0.9-6 \times 0.6-2 \mathrm{~cm} \ldots$ C. tenuis Rchb. f.

23. Leaf blade broadly ovate to broadly elliptic; petiole at least $1 \mathrm{~cm}$ long; blade $4-8 \times 2-4 \mathrm{~cm} \ldots 24$ 24. Petiole up to $2.5 \mathrm{~cm}$ long, lip unlobed ....... $\ldots \ldots \ldots \ldots \ldots \ldots$ C. parvula $\mathrm{Renz}$ 24. Petiole up to $9 \mathrm{~cm}$ long, lip 3-lobed at apex . . C. pulvinifera Garay

ACKNOWLEDGEMENTS. The curators and staff of the cited herbaria are thanked for their kind hospitality and assistance during visits and for making specimens available on loan. We are grateful to Anna Król and Sławomir Nowak for preparing the illustrations and to the anonymous reviewers for helpful remarks on the manuscript. The research described here was supported by the Polish Ministry of Science and Higher Education (research grant no. 8124/B/PO1/2011/40).

\section{REFERENCES}

ACUÑA J. 1939. Catalogo descriptivo de las Orquideas Cubanas. Boletín Estación Experimental Agronómica, Santiago de las Vegas, provincia de La Habana 60: 1-221.

Álvarez-Molina A. \& CAMERon K. M. 2009. Molecular phylogenetics of Prescottiinae s.l. and their close allies (Orchidaceae, Cranichideae) inferred from plastid and nuclear ribosomal DNA sequences. Amer. J. Bot. 96(5): 1020-1040.

Carnevali G. \& Ramírez-Morillo I. M. 2003. Cranichis. In: J. A. Steyermark, P. E. Berry, K. YATSKIEVyCH \& B. K. Holst (eds), Flora of the Venezuelan Guayana. 7. Missouri Botanical Garden Press, St. Louis.

CribB P. 2003. Cranichis. In: A. M. Pridgeon, P. J. CRIBB, M. W. ChASE \& F. N. RASMUSSEN (eds), Genera Orchidacearum. 3. Oxford University Press, Oxford.

DRESSLER R. L. 1993. Phylogeny and classification of the orchid family. Dioscorides Press, Portland.

Dueñas Gómez H. C. \& Fernández-Alonso J. L. 2007. Sinopsis de la subfamilia Spiranthoideae (Orchidaceae) en Colombia, parte I. Revista Acad. Colomb. Ci. Exact. 31: 5-27.

Dueñas Gómez H. C. \& FernÁndeZ-Alonso J. L. 2009. Sinopsis de la subfamilia Spiranthoideae (Orchidaceae) en Colombia, parte II. Revista Acad. Colomb. Ci. Exact. 33: $157-181$.

ORMEROD P. 2007. Studies of Neotropical Goodyerinae (Orchidaceae) 2. Harvard Pap. Bot. 11(2): 145-177.

ORMEROD P. 2008. Studies of Neotropical Goodyerinae (Orchidaceae) 3. Harvard Pap. Bot. 13: 55-87.

Ormerod P. 2009a. Notulae Goodyerinae (IV). Taiwania 54(1): 45-51.

ORMEROD P. 2009b. Studies of neotropical Goodyerinae (Orchidaceae) 4. Harvard Pap. Bot. 14(2): 111-129.

ORTIZ VALdivieso P. \& URIBE VÉLEZ C. 2007. Galería de Orquídeas de Colombia (CD edition). Asociación Bogotana de Orquideología, Bogotá.

Salazar G. A., Chase M. W., Soto Arenas M. I. \& INGROUILLE M. 2003. Phylogenetics of Cranichideae with emphasis on Spiranthinae (Orchidaceae, Orchidoideae): evidence from plastid and nuclear DNA sequences. Am. J. Bot. 90(5): 777-795.

SCHNEIDER M. 1953. El Género Cranichis (Orchidaceae) en Colombia. Caldasia 6: 11-18. 
Swartz O. 1788. Nova Genera Species Plantarum seu Prodromus descriptionum Vegetabilium maximam partem incognitorum quae sub itinere Indiam Occidentalem annis 1783-87. Bibliopoliis Acad. M. Swederi, Holmiæ, Upsaliæ \& Aboæ.

SZLACHETKO D. L. 1995. Systema orchidalium. Fragm. Florist. Geobot., Suppl. 3: 1-152.
SzlachetKo D. L. \& KolanowsKa M. 2013 New species of the genus Cranichis (Orchidaceae, Cranichidinae) from Colombia. Plant Syst. Evol. 299: 979-983.

SzlachetKo D. L. \& RutKowski P. 2000. Gynostemia Orchidalium Vol. 1 Apostasiaceae, Cypripediaceae, Orchidaceae (Thelymitroideae-Vanilloideae). Acta Bot. Fenn. 169: $1-380$.

Received 19 April 2013 